\title{
Identification and in Vitro Susceptibility Pattern of Fungal Pathogens in Immunocomprimised Patients with Pulmonary Fungal Infections
}

\author{
HANAN H. ABD EL-LATEEF, M.D.*; AHMED M. MOHARRAM, M.D.**; MAHA M. EL-KHOLY, M.D.***; \\ SOHAIR K. SAYED, M.D.*; MOHAMMED Z. ABD EL-RAHMAN, M.D.* and \\ DOAA M. ABD EL-KAREEM, M.Sc.*
}

The Departments of Clinical Pathology, Faculty of Medicine*, Botany \& Microbiology, Faculty of Science ${ }^{* *}$ and Chest Diseases, Faculty of Medicine***, Assiut University, Assiut, Egypt

\begin{abstract}
Background: The frequency of fungal infections of the lung has increased particularly in immunocompromised patients. Early diagnosis and treatment is important to start antifungal therapy and to avoid unnecessary use of toxic antifungal agents. This study aimed to identify the common fungal species causing pulmonary infection in immunocompromised patients and their in vitro antifungal sensitivity pattern in Assiut University Hospitals (AUH).
\end{abstract}

Subjects and Methods: This was a hospital based descriptive study conducted on 135 patients admitted at different Intensive Care Units (ICUs) and Oncology Department at Assiut University Hospitals (AUH). Collected respiratory specimens were subjected to direct microscopic examination and inoculation on Sabouraud Dextrose Agar (SDA). Identification of isolated yeasts was done using phenotypic methods including chromogenic media (Brilliance Candida agar and CHROMagar Candida differential media), germ tube test, cornmeal agar and API candida while mould isolates identification was mainly dependent on macroscopic and microscopic features. Some isolates had confirmed using rRNA gene sequencing. In vitro antifungal susceptibility testing was done using disc diffusion method.

Results: In this study 80/135 (59.3\%) of collected samples were positive for fungal infection. The most common fungal pathogens isolated were Candida and Aspergillus species. In vitro sensitivity test showed that the yeast isolates had the highest sensitivity to Nystatin $(90.9 \%)$ followed by Amphotericin B $(80.3 \%)$ while for mould isolates, the highest sensitivity was to Voriconazole (71.4\%) followed by Amphotericin B $(57.1 \%)$.

Conclusion: Pulmonary fungal infection appears to be an important problem in immunocomprimised patients with Candida albicans was the most commonly isolated yeast from various clinical specimens; also the increase in the resistance especially to azoles is a major concern.

Correspondence to: Dr. Doaa M. Abd El-Kareem, E-Mail: doaa60160@yahoo.com
Key Words: Pulmonary fungal infection - Candida-Asergillus - Antifungal agents.

\section{Introduction}

THE incidence of fungal infections is increasing at an alarming rate, presenting an enormous pressure and challenge to healthcare professionals for their diagnosis and treatment. Emerging fungal infections is also cause of significant morbidity and mortality. This emergence is directly related to the growing population of immune-compromised individuals. Patient with condition such as granulocytopenia, advanced HIV infection, bone marrow and solid organ transplantation, cancer, diabetes mellitus, severe burn and trauma and severe malnutrition are among many others predisposing factor for low immunity [1]

Invasive fungal infection is a major cause of morbidity and mortality in immunocompromised patients, case mortality in fungal pneumonias can be as high as $90 \%$ in immunocompromised patients

The mortality of fungal respiratory infections has remained high despite the advent of new antifungal therapies. The lack of specific signs of infection and the low sensitivity of conventional culture-based methods for diagnosis of fungal diseases result in delayed initiation of antifungal therapy. The early recognition and treatment of these infections are crucial for optimal outcome and represent a major challenge for the clinicians

In immunocompromised patients, any fungus present in the environment may be potentially 
pathogenic. Aspergillus and Candida spp. are the main organisms isolated most frequently from immunocompromised patients. The other most relevant aetiologic agents are Cryptococcus spp., Fusarium spp., Zygomycete, Dematiaceous fungi and opportunistic yeast-like fungi [4]

Due to the poor outcome related to Invasive Fungal Infections (IFIs) in critically ill patients, the knowledge of local epidemiologic trends and antifungal susceptibility of etiological agents is critical [5].

Antifungal susceptibility testing methods are available to detect antifungal resistance and to determine the best treatment for a specific fungus. Clinical microbiology relies on these methods to select the agent of choice for a fungal infection, and to know the local and the global epidemiology of antifungal resistance [6].

Compared to antibacterial drugs, antimicrobial agents available for treatment of invasive fungal infections are sparse. Amphotericin B (polyene) was the first drug introduced in the 1950s, followed by flucytosine (pyrimidine) in the 1970s, and firstgenerations azoles (fluconazole, itraconazole) in the 1990s. Triazoles (voriconazole, posaconalzole) and echinocandins (caspofungin, micafungin, anidulafungin) became available more recently, with isavuconazole added in 2015. Although most fungi remain susceptible to many of these drugs, expanding use of antifungal therapy due to a steadily growing immunocompromised population and potentially the use of azoles in agriculture, has led to elevated resistance rates among clinical isolates [7].

The present study was undertaken to identify the common fungal species causing pulmonary infection in immunocompromised patients and their in vitro antifungal sensitivity pattern in Assiut University Hospitals (AUH).

\section{Material and Methods}

\section{- Study design and population:}

This hospital based descriptive study was carried out in Microbiology Unit, Clinical Pathology Department at Assiut University Hospital and Assiut University Mycology Center (AUMC), Faculty of Science, Assiut University, Assiut, Egypt during the period from September 2014 to May 2016. The study included 135 patients who were admitted to different Intensive Care Units (ICUs) of Chest, Tropical Medicine, Trauma ICU, General ICU, Hematology ICU and Oncology Department at Assiut University Hospitals. Samples collected from the patients included: Sputum samples $(n=37)$, endotracheal tube aspirates $(\mathrm{n}=42)$ and Bronchoalveolar Lavage (BAL) $(\mathrm{n}=56)$.

- Laboratory processing of samples:

A- Direct microscopic examination: Direct smears from samples were prepared and examined using Lactophenol Cotton Blue (LCB) as recommended by Ellis et al., [8]

$B$-Culturing of samples: Samples were streaked on the surface of two Sabouraud dextrose agar (HiMedia, India) plates supplemented with chloramphenicol $(0.5 \mathrm{mg} / \mathrm{l})$. One was incubated at $37^{\circ} \mathrm{C}$ and the other at $25^{\circ} \mathrm{C}$ to $27^{\circ} \mathrm{C}$ for at least 2 weeks with daily examination until fungal colonies appear or reported as negative. Cultures were also preserved on SDA slant agar for further studies.

\section{$C$ - Identification of fungi:}

1- Phenotypic identification:

- Identification of yeast isolates:

- Culture on different chromogenic media (Brilliance Candida agar (Oxoid Company, UK) and CHROMagar Candida differential medium (CHROMagar Company, Paris, France): To detect mixed yeast infections and to provide presumptive identification of some yeast isolates according to colony colour as described in the included pamphlet.

- Germ tube test: This is a rapid method for identifying and differentiating C. albicans from other Candida spp. [8].

- Inoculation of yeast isolates on cornmeal agar (HiMedia, India); Dalmau plate technique to identify Candida species via chlamydospores production [9].

- API Candida (BioMérieux, France): Some isolates were confirmed by assimilation of sugars test using API strips according to manufactures instructions which allow the performance of 12 identification tests.

\section{- Identification of mould isolates:}

- Identification of filamentous fungi is mainly dependent on morphologic features as detected macroscopically and microscopically (in LCB stained wet mounts). Filamentous fungi isolates were identified directly after sufficient growth was obtained on SDA [10,11]

\section{2- Genotypic identification:}

Some fungal isolates were selected and individually grown on SDA and incubated at $28^{\circ} \mathrm{C}$ for 3 days. A small amount of fungal growth was scrapped and suspended in 100 Lavoclaved distilled water in $2 \mathrm{ml}$ sterile vials and boiled at $100^{\circ} \mathrm{C}$ 
for 15 minutes and stored at $70^{\circ} \mathrm{C}$. Samples were sent to SolGent Company (Daejeon, South Korea) for rRNA gene sequencing. Fungal DNA was extracted and isolated using SolGent purification bead. Prior to sequencing, the ribosomal rRNA gene was amplified using the Polymerase Chain Reaction (PCR) technique in which two universal fungal primers ITS 1 (forward) and ITS4 (reverse) were incorporated in the reaction mixture. Primers used for gene amplification have the following composition: ITS 1 (5'-TCC GTA GGT GAA CCT GCG G-3'), and ITS4 (5'-TCC TCC GCT TAT TGA TAT GC-3'). PCR products were sequenced in the sense and antisense directions using ITS 1 and ITS4 primers [12]. Sequences were further analyzed using BLAST from the National Center of Biotechnology Information (NCBI) website [13]

D- Antifungal susceptibility testing: Antifungal susceptibility testing of isolated fungi was performed using the disc diffusion method according to the procedure described in the CLSI M44-A and M51-A document $[\mathbf{1 4 , 1 5}]$. Antifungal agents tested were: Polyenes; (Amphotericin B 100 units and Nystatin 100 units), azoles; (Fluconazole $25 \mu \mathrm{g}$, Ketoconazole $10 \mu \mathrm{g}$, Itraconazole $10 \mu \mathrm{g}$, Voriconazole $1 \mu \mathrm{g})$.

\section{Results}

\section{1- Direct Microscopic Examination (DME) and culture of specimens:}

Out of the 135 samples, direct microscopic examination showed that $17(12.6 \%)$ were diagnosed as positive for fungal infection while 80 (59.3\%) were positive for fungal growth when inoculated on Sabouraud Dextrose Agar (SDA). Out of these 80 positive samples, $13(8.9 \%)$ showed mixed fungal infection while in the remaining 67 $(50.4 \%)$ infection was caused by a single fungus as shown in (Table 1).

\section{2- Identification of isolated fungi.}

A- Identification of yeast isolates: Out of the 80 positive cultures, 66 yeast isolates were isolated, of which 63 yeast isolates $(95.5 \%)$ were identified on basis of phenotypic characters on Brilliance Candida agar, CHROMagarTM Candida Fig. (1) Cornmeal Agar (CMA) and by Germ tube test while 3 isolates $(4.5 \%)$ could not identified phenotypically. These isolates identified using API Candida and rRNAgene sequencing. Phenotypic characteristics of isolated yeast isolates with results of germ tube test were summarized.

Table (1): Direct Microscopic examination and culture of studied specimens

\begin{tabular}{lcccc}
\hline & $\begin{array}{c}\text { Bronchial lavage } \\
(\mathrm{n}=56)\end{array}$ & $\begin{array}{c}\text { Endotracheal tube } \\
\text { aspirate }(\mathrm{n}=42)\end{array}$ & $\begin{array}{c}\text { Sputum } \\
(\mathrm{n}=37)\end{array}$ & $\begin{array}{c}\text { Total } \\
(\mathrm{n}=135)\end{array}$ \\
\hline $\begin{array}{l}\text { DME: No (\%): } \\
\quad \text { Positive }\end{array}$ & $8(14.3)$ & $4(9.5)$ & $5(13.5)$ & $17(12.6)$ \\
$\quad$ Negative & $48(85.7)$ & $38(90.5)$ & $32(86.5)$ & $118(87.4)$ \\
$\begin{array}{l}\text { Culture on SDA: No. (\%): } \\
\quad \text { Positive }\end{array}$ & $27(48.2)$ & $26(61.9)$ & $27(73)$ & $80(59.3)$ \\
$\quad$ Negative & $29(51.8)$ & $16(38.1)$ & $10(27)$ & $55(40.7)$ \\
Type of infection: No. (\%): & & & & \\
$\quad$ Negative & $29(51.8)$ & $16(38.1)$ & $10(27)$ & $55(40.7)$ \\
$\quad$ Single & $24(42.9)$ & $22(52.4)$ & $21(59.5)$ & $67(50.4)$ \\
$\quad$ Mixed & $3(5.4)$ & $4(9.5)$ & $6(13.5)$ & $13(8.9)$ \\
\hline
\end{tabular}

$\mathrm{N}$ : Number.

DME: Direct Microscopic Examination.

SDA: Sabouraud Dextrose Agar.
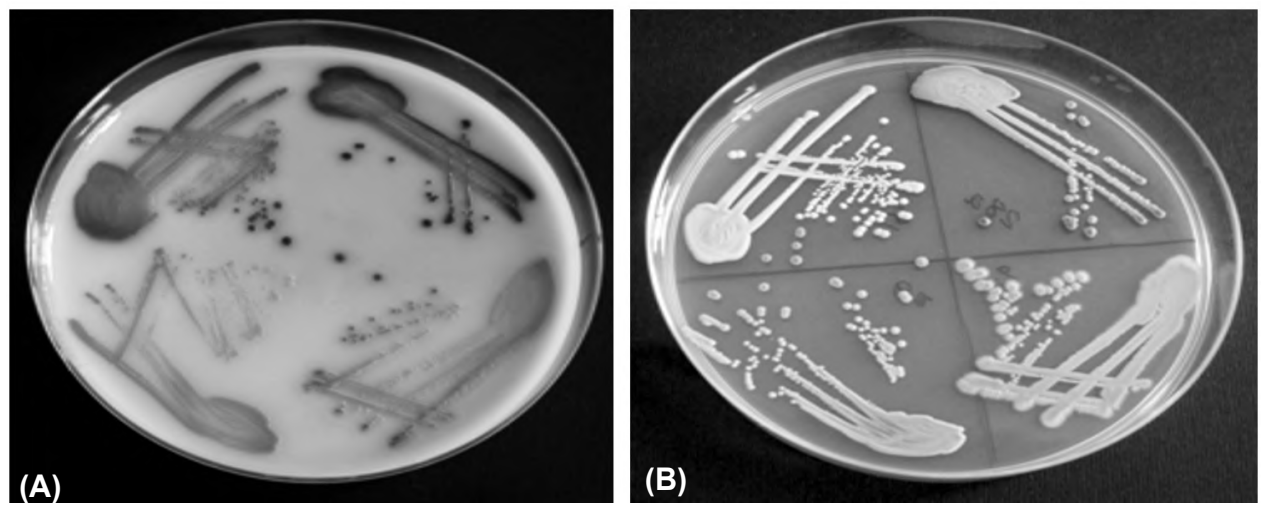

Fig. (1): Colony colour of Candia isolates on chromogenic media; (A) Brilliance Candida agar, (B) CHROMagar Candida. 
Table (2): Total number and percentage of yeast isolates after presumptive identification based on phenotypic characteristics.

\begin{tabular}{|c|c|c|c|c|}
\hline $\begin{array}{l}\text { Presumptive } \\
\text { identification }\end{array}$ & $\begin{array}{l}\text { Brilliance } \\
\text { candida agar }\end{array}$ & CHROMagar & $\begin{array}{l}\text { Germ tube } \\
\text { test }\end{array}$ & CMA \\
\hline C. albicans, $38(57.6 \%)$ & Green & Green & $\begin{array}{l}36+\mathrm{ve} \\
1-\mathrm{ve}\end{array}$ & $\begin{array}{l}\text { - Terminal chlamydospores with abundant } \\
\text { pseudohyphae. }\end{array}$ \\
\hline C. glabrata, $11(16.7 \%)$ & Beige & Dark pink & $-\mathrm{ve}$ & $\begin{array}{l}\text { - Budding yeast cells only. No pseudohyphae. } \\
\text { No chlamydospores. }\end{array}$ \\
\hline \multicolumn{5}{|l|}{ C. tropicals, 10 (15.1\%): } \\
\hline$-8(12.1 \%)$ & Dark blue & Blue gray & $-\mathrm{ve}$ & $\begin{array}{l}\text { - Abundant pseudohyphae with no } \\
\text { chlamydospores production. }\end{array}$ \\
\hline$-2(3 \%)$ & Dark blue & Dark blue with halo & + ve & $\begin{array}{l}\text { - Abundant pseudohyphae with no } \\
\text { chlamydospores production. }\end{array}$ \\
\hline C. krusei, 4 (6.1\%) & Pink brown & Pink fuzzy & $-\mathrm{ve}$ & $\begin{array}{l}\text { - Extensive branched pseudomycelium with } \\
\text { chains of elongate cells giving tree-like } \\
\text { appearance. No chlamydospore production. }\end{array}$ \\
\hline$-2(3 \%)$ & Mouve & Small pink & $-\mathrm{ve}$ & - Budding blastoconidia. No chlamydospores. \\
\hline$-1(1.5 \%)$ & Mouve & Mouve & $-\mathrm{ve}$ & No pseudohyphae \\
\hline
\end{tabular}

Using conventional methods, one isolate was identified to be C. glabrata while it was identified as C. kefyr by both API and rRNA sequencing methods. The three unidentified isolates were identified by rRNA sequencing to be two Saccharomyces paradoxus strains and one Hanseniaspora guilliermondii strain.

In conclusion, phenotypic and genotypic characterization of yeast isolates showed that the percentages of yeast strains were: C. albicans $57.5 \%$, C. glabrata $15.1 \%$, C. tropicalis $15.1 \%$, C. krusei $6.1 \%$, C. kefyr $1.5 \%$, Saccharomyces paradoxus $3 \%$ and Hanseniaspora guilliermondii $1.5 \%$ Fig. (2).
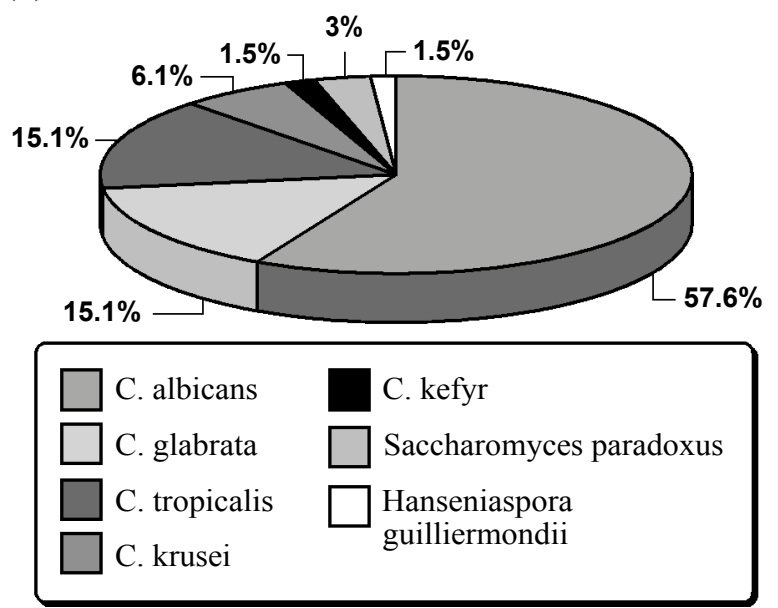

Fig. (2): Groups of yeast strains (after sequencing of rRNA gene).

B- Identification of isolated filamentous fungi: Out of the 80 positive cultures, 28 mould isolates were isolated, which identified phenotypically as A. flavus 10 isolates $(35.6 \%)$, A. niger 9 isolates ( $32.1 \%)$, A. parasiticus 2 isolates (7.1\%) and A. terreus, A. tubingensis, A. fumigatus, Absidia corymbifera, penicillium chrysogenum, Rhizopus stolonifer, Syncephalastrum racemosum one isolate each $(3.6 \%)$.

Genotypic identification via sequencing of rRNA gene was carried out for 6 different isolates of filamentous fungi for confirmation and revealed that identification obtained by phenotypic methods was concordant with sequencing analysis to genus level. Discordant results occurred in two isolates which were identified as Rhizopus oryzae and syncephalastrum monosporum while they were identified phenotypically as Rhizopus stolonifer and Syncephalastrum racemosum respectively.

In conclusion, the percentages of mould strains after sequencing of rRNA gene were: A. flavus $35.6 \%$, A. niger $32.1 \%$, A. parasiticus $7.1 \%$, A. terreus $3.6 \%$, A. tubingensis $3.6 \%$, A. fumigatus $3.6 \%$, Absidia corymbifera $3.6 \%$, Penicillium chrysogenum $3.6 \%$, Rhizopus oryzae $3.6 \%$ and Syncephalastrum monosporum $3.6 \%$ as shown in Fig. (3).

\section{3- Antifungal Susceptibility Testing (AST):}

A- Antifungal susceptibility testing of isolated yeasts: The different yeast isolates (66 isolates) were tested for their sensitivity to 6 types of antifungal therapeutic agents as shown in Fig. (4). Data in (Table 3) and Fig. (5) showed that the most active drugs were, Nystatin, Amphotericine B and Voriconazole affecting 90.9\%$80.3 \%-39.4 \%$ of strains. 
Table (3): Antifungal susceptibility pattern of yeast strains in the current study.

\begin{tabular}{|c|c|c|c|c|c|c|c|c|}
\hline & $\begin{array}{c}\text { C. albicans } \\
(\mathrm{n}=38)\end{array}$ & $\begin{array}{l}\text { C. glabrata } \\
(\mathrm{n}=10)\end{array}$ & $\begin{array}{l}\text { C. tropical } \\
(\mathrm{n}=10)\end{array}$ & $\begin{array}{l}\text { C. Krusei } \\
(\mathrm{n}=4)\end{array}$ & $\begin{array}{c}\text { C. kefyr } \\
(\mathrm{n}=1)\end{array}$ & $\begin{array}{l}\text { Hanseniaspora } \\
\text { guilliermondii } \\
\qquad(\mathrm{n}=1)\end{array}$ & $\begin{array}{c}\text { Saccharomyces } \\
\text { paradoxus } \\
(\mathrm{n}=2)\end{array}$ & $\begin{array}{c}\text { Total } \\
(n=66)\end{array}$ \\
\hline \multicolumn{9}{|l|}{ FFluconazole: } \\
\hline Sensitive & $15(39.5)$ & $4(40)$ & $5(50)$ & 0 & 0 & 0 & $1(50)$ & $25(37.9)$ \\
\hline Intermediate & $2(5.3)$ & & $1(10)$ & 0 & 0 & 0 & & $3 \quad(4.5)$ \\
\hline Resistant & $21(55.2)$ & $6(60)$ & $4(40)$ & $4(100)$ & $1(100)$ & $1(100)$ & $1(50)$ & $38(57.6)$ \\
\hline \multicolumn{9}{|l|}{ Nystatin: } \\
\hline Sensitive & $35(92.1)$ & $9(90)$ & $8(80)$ & $4(100)$ & $1(100)$ & $1(100)$ & $2(100)$ & $60(90.9)$ \\
\hline Intermediate & $2(5.3)$ & $1(10)$ & $2(20)$ & 0 & 0 & 0 & 0 & $5 \quad(7.6)$ \\
\hline Resistant & $1 \quad(2.6)$ & 0 & 0 & 0 & 0 & 0 & 0 & $1 \quad(1.5)$ \\
\hline \multicolumn{9}{|l|}{ Voriconazole: } \\
\hline Sensitive & $7 \quad(18.4)$ & $7(70)$ & $6(60)$ & $4(100)$ & $1(100)$ & $1(100)$ & 0 & $26(39.4)$ \\
\hline Intermediate & $4 \quad(10.5)$ & 0 & 0 & 0 & 0 & 0 & $1(50)$ & $5 \quad(7.6)$ \\
\hline Resistant & $27(71.1)$ & $3(30)$ & $4(40)$ & 0 & 0 & 0 & $1(50)$ & $35(53)$ \\
\hline \multicolumn{9}{|l|}{ Amphotericin B: } \\
\hline Intermediate & $\begin{array}{l}31(81.6) \\
3 \quad(7.9)\end{array}$ & $\begin{array}{l}\gamma(80) \\
2(20)\end{array}$ & $\begin{array}{l}8(80) \\
1(10)\end{array}$ & $\begin{array}{l}2(50) \\
1(25)\end{array}$ & 0 & 0 & $\begin{array}{l}2(100) \\
0\end{array}$ & $\begin{array}{l}53(80.3) \\
7 \quad(10.6)\end{array}$ \\
\hline Resistant & $4 \quad(10.5)$ & 0 & $1(10)$ & $1(25)$ & 0 & 0 & 0 & 6 (9.1) \\
\hline \multicolumn{9}{|l|}{ Ketoconazole: } \\
\hline Sensitive & $9 \quad(23.7)$ & $2(20)$ & $5(50)$ & $4(100)$ & $1(100)$ & 0 & 0 & $21(31.8)$ \\
\hline Intermediate & 7 (18.4) & $2(20)$ & $1(10)$ & 0 & 0 & 0 & $1(50)$ & $11(16.7)$ \\
\hline Resistant & $22(57.9)$ & $6(60)$ & $4(40)$ & 0 & 0 & $1(100)$ & $1(50)$ & $34(51.5)$ \\
\hline \multicolumn{9}{|l|}{ Itraconazole: } \\
\hline Sensitive & 0 & $1(10)$ & 0 & 0 & $1(100)$ & 0 & 0 & $2(3)$ \\
\hline Intermediate & $11(28 . .9)$ & $4(40)$ & $4(40)$ & $1(25)$ & 0 & 0 & $1(50)$ & $21(31.8)$ \\
\hline Resistant & $27(71.1)$ & $5(50)$ & $6(60)$ & $3(75)$ & 0 & $1(100)$ & $1(50)$ & $43(65.2)$ \\
\hline
\end{tabular}

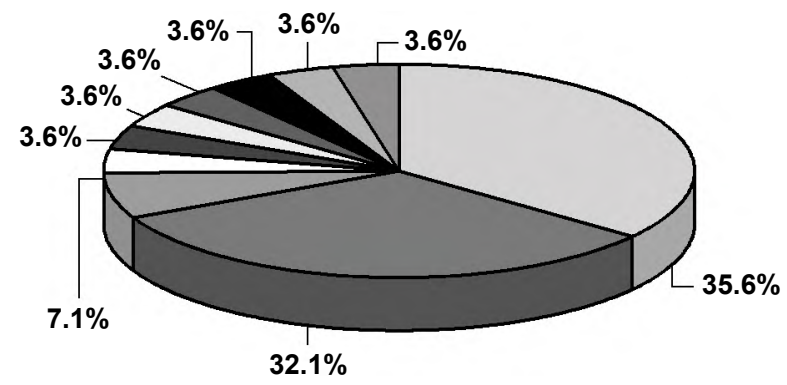

\begin{tabular}{|ll|}
\hline A. flavus & $\square$ A. fumigatus \\
$\square$ A. niger & Absidia corymbifera \\
Penicillium chrysogenum \\
\hline A. parasiticus & Rhizopus oryzae \\
\hline A. terreus & Syncephalastrum monosporum \\
\hline & A. tubingensis \\
\hline
\end{tabular}

Fig. (3): Percentage of isolated mould strains (after sequencing of rRNA gene).

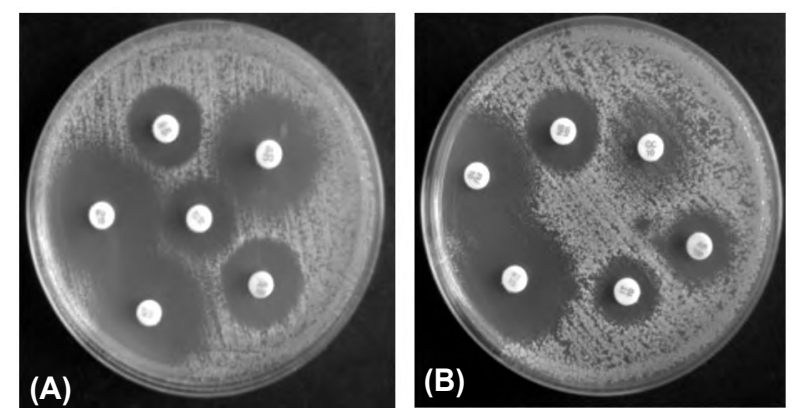

Fig. (4): Antifungal susceptibility testing of isolated fungi; (A) C. albicans, (B) C. tropicalis

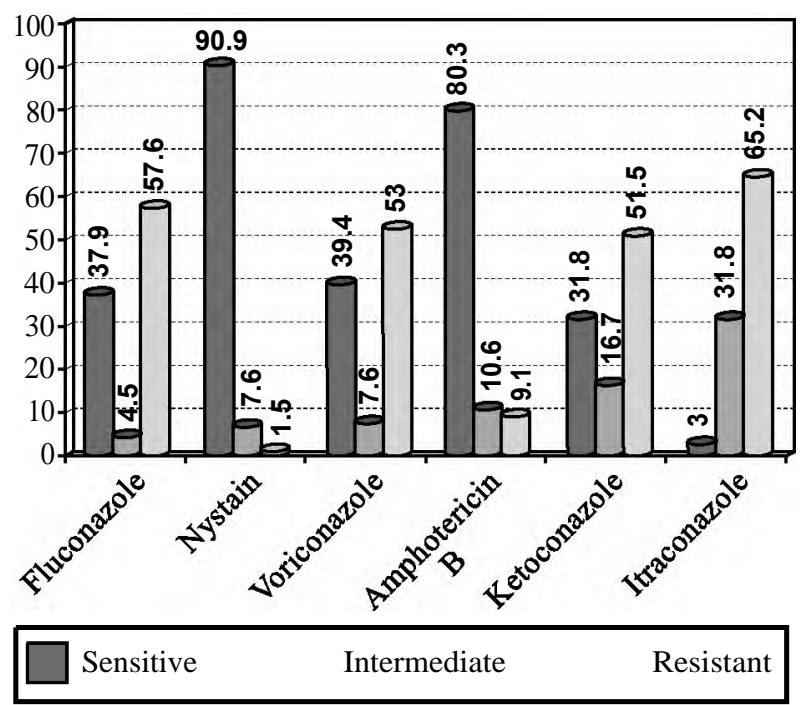

Fig. (5): Percentage of antifungal susceptibility pattern of yeast strains.

B- Antifungal susceptibility testing of isolated filamentous fungi: Mould strains (28) were tested for their susceptibility Fig. (6). The highest percentage of sensitivity among mould strains was to Voriconazole $71.4 \%$, Amphotericin B $57.1 \%$ then Nystatin 50\% while the highest resistance was to Fluconazole $92.8 \%$ followed by Itraconazole $75 \%$ as shown in (Table 4 ) and Fig. (7). 
Table (4): Antifungal susceptibility pattern of mould strains in the current study.

\begin{tabular}{|c|c|c|c|c|c|c|}
\hline & Fluconazole & Nystatin & Voriconazole & Amphotericin B & Ketoconazole & Itraconazole \\
\hline \multicolumn{7}{|l|}{ A. flavus $(n=10)$ : } \\
\hline Sensitive & 0 & $3(30)$ & $6(60)$ & $5(50)$ & $4(40)$ & $2(20)$ \\
\hline Intermediate & 0 & $2(20)$ & $1(10)$ & $2(20)$ & $1(10)$ & $2(20)$ \\
\hline Resistant & $10(100)$ & $5(50)$ & $3(30)$ & $3(30)$ & $5(50)$ & $6(60)$ \\
\hline \multicolumn{7}{|l|}{ A. niger $(n=9)$ : } \\
\hline Sensitive & 0 & $4(44.4)$ & $8(88.9)$ & $7(77.8)$ & 0 & 0 \\
\hline Intermediate & $1(11.1)$ & $1(11.2)$ & $1(11.1)$ & $1(11.1)$ & $3(33.3)$ & $1(11.1)$ \\
\hline Resistant & $8(88.9)$ & $4(44.4)$ & 0 & $1(11.1)$ & $6(66.7)$ & $8(88.9)$ \\
\hline \multicolumn{7}{|c|}{ A. parasiticus $(n=2)$ : } \\
\hline Sensitive & $1(50)$ & $1(50)$ & $2(100)$ & $1(50)$ & $2(100)$ & 0 \\
\hline Intermediate & 0 & 0 & 0 & 0 & 0 & 0 \\
\hline Resistant & $1(50)$ & $1(50)$ & 0 & $1(50)$ & 0 & $2(100)$ \\
\hline \multicolumn{7}{|l|}{ A. terreus $(n=1)$ : } \\
\hline Sensitive & 0 & $1(100)$ & $1(100)$ & 0 & $1(100)$ & $1(100)$ \\
\hline Intermediate & 0 & 0 & 0 & 0 & 0 & 0 \\
\hline Resistant & $1(100)$ & 0 & 0 & $1(100)$ & 0 & 0 \\
\hline \multicolumn{7}{|c|}{ A. tubingensis $(n=1)$ : } \\
\hline Sensitive & 0 & $1(100)$ & $1(100)$ & $1(100)$ & 0 & 0 \\
\hline Intermediate & 0 & 0 & 0 & 0 & $1(100)$ & 0 \\
\hline Resistant & $1(100)$ & 0 & 0 & 0 & 0 & $1(100)$ \\
\hline \multicolumn{7}{|c|}{ A. fumigatus $(n=1)$ : } \\
\hline Sensitive & 0 & $1(100)$ & $1(100)$ & $1(100)$ & 0 & $1(100)$ \\
\hline Intermediate & 0 & 0 & 0 & 0 & 0 & 0 \\
\hline Resistant & $1(100)$ & 0 & 0 & 0 & $1(100)$ & 0 \\
\hline \multicolumn{7}{|c|}{ Absidia corymbifera $(n=1)$ : } \\
\hline Sensitive & 0 & $1(100)$ & $1(100)$ & 0 & 0 & 0 \\
\hline Intermediate & 0 & 0 & 0 & 0 & 0 & 0 \\
\hline Resistant & $1(100)$ & 0 & 0 & $1(100)$ & $1(100)$ & $1(100)$ \\
\hline \multicolumn{7}{|c|}{ Rhizopus oryzae $(n=1)$ : } \\
\hline Sensitive & 0 & $1(100)$ & 0 & 0 & 0 & 0 \\
\hline Intermediate & 0 & 0 & 0 & 0 & 0 & 0 \\
\hline Resistant & $1(100)$ & 0 & $1(100)$ & $1(100)$ & $1(100)$ & $1(100)$ \\
\hline \multicolumn{7}{|c|}{ Penicillium chrysogenum $(n=1)$ : } \\
\hline Sensitive & 0 & 0 & 0 & 0 & 0 & 0 \\
\hline Intermediate & 0 & 0 & 0 & 0 & 0 & 0 \\
\hline Resistant & $1(100)$ & $1(100)$ & $1(100)$ & $1(100)$ & $1(100)$ & $1(100)$ \\
\hline \multicolumn{7}{|c|}{ Syncephalastrum monosporum $(n=1)$ : } \\
\hline Sensitive & 0 & $1(100)$ & 0 & $1(100)$ & 0 & 0 \\
\hline Intermediate & 0 & 0 & 0 & 0 & 0 & 0 \\
\hline Resistant & $1(100)$ & 0 & $1(100)$ & 0 & $1(100)$ & $1(100)$ \\
\hline \multicolumn{7}{|l|}{ Total $(n=28)$ : } \\
\hline Sensitive & 1 (3.6) & $14(50)$ & $20(71.4)$ & $16(57.1)$ & $7 \quad(25)$ & $4 \quad(14.3)$ \\
\hline Intermediate & 1 (3.6) & $3 \quad(10.7)$ & $2(7.2)$ & $3 \quad(10.7)$ & $5 \quad(17.8)$ & $3 \quad(10.7)$ \\
\hline Resistant & $26(92.8)$ & $11(39.3)$ & $6 \quad(21.4)$ & $9 \quad(32.2)$ & $16(57.2)$ & $21(75)$ \\
\hline
\end{tabular}



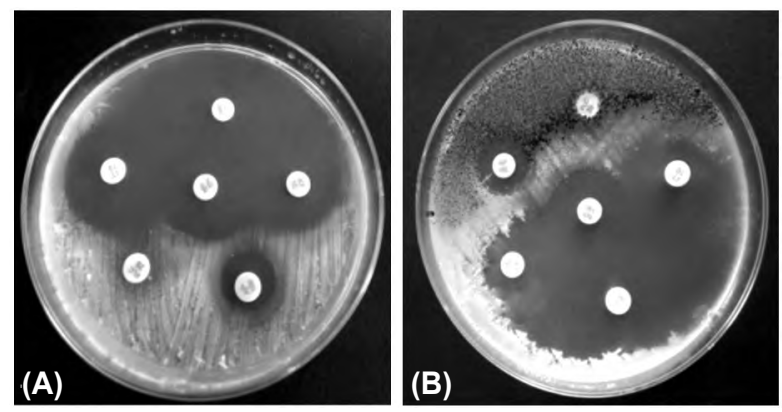

Fig. (6): Antifungal susceptibility testing of isolated fungi; (A) A. terreus (B) A. niger.

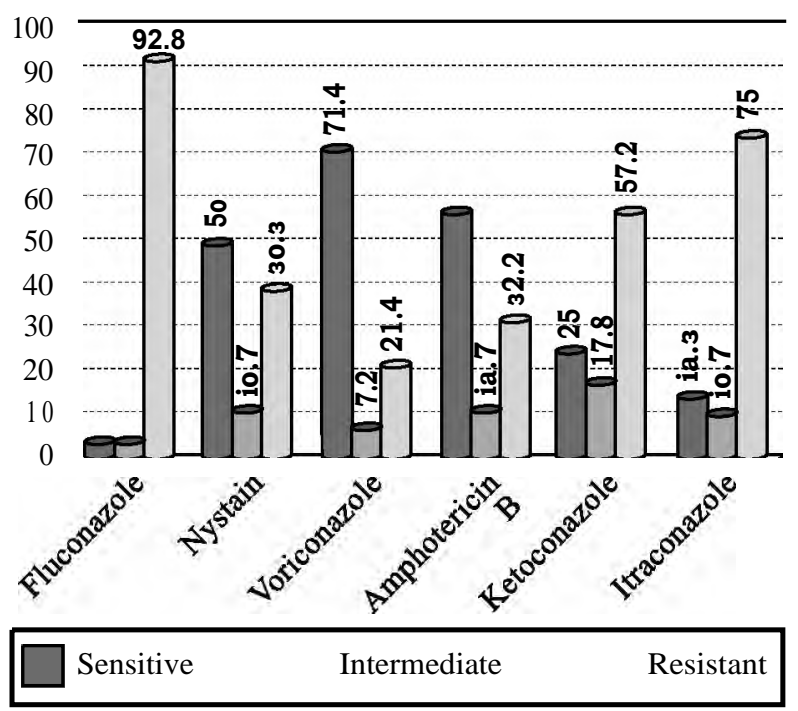

Fig. (7): Percentage antifungal susceptibility pattern of mould strains.

\section{Discussion}

Fungal infections of the lung are among the most feared infections occurring in immunocompromised patients [16]. Microscopic examination represents a rapid aid in the diagnosis of many fungal infections via detection of fungal elements (budding yeasts, pseudohyphae and/or hyphae) in tissue specimens or samples of body fluids. Although the diagnostic yield may range from $10 \%$ to more than $90 \%$ depending on the fungal species, diagnostic microscopic examination should be used whenever possible because of the relatively inexpensive cost and rapid availability of data [17]

In our study, only 17/135 (12.6\%) samples were diagnosed as positive by Direct Microscopic Examination (DME). These results were consistent with those of Njunda et al., [18] whom revealed that 27/200 (11.5\%) sputum samples were positive for fungal infection on DME while in a study by Zarrinfar et al., [19] on 400 bronchoalveolar lavage samples, $16(4 \%)$ were positive by direct microscopic examination.
Culture from a clinical sample is the gold standard for diagnosis of fungal infection. Culture has the advantage of yielding the specific etiological agent if positive. Moreover, culture allows for susceptibility testing [20]. In the current study, out of the 135 samples analyzed, $80(59.3 \%)$ were positive for fungal growth when inoculated on SDA. These results were consistent with Gupta et al., [21] who found that $109 / 200(54.5 \%)$ sputum samples of patients with Bronchopulmonary disorders were found positive of fungi. Nasir et al., [22] found that $102 / 150(68 \%)$ sputum samples were positive for fungal infection among HIV infected patients which is higher than our results. While Taura et al., [23] reported that 80/200 (40\%) sputum samples were positive for fungal infection.

It is notable that although the distribution of Candida species varied across geographic regions, C. albicans remains the predominantly isolated species [24]. However, a shift towards non-albicans Candida species has been observed [25], mainly due to severe immunosuppression, use of broadspectrum antibiotics and empirical use of antifungal drugs. In our study, Candida albicans was the most frequently isolated species $(57.5 \%)$, followed by C. glabrata (15.1\%), C. tropicalis $(15.1 \%)$, C. krusei $(6.1 \%)$, and C. kefyr (1.5\%). Our findings are in agreement with Magalhães et al., [26] who found that $\mathrm{C}$. albicans was the most prevalent species in respiratory tract followed by $\mathrm{C}$. tropicalis and C. glabrata and with those of Shawky et al., [27] in Alexandria University in Egypt who reported that in respiratory samples C. albicans was the most frequent species isolated $43.3 \%$ followed by C. glabrata (28\%) and C. tropicalis (18.7\%).

Mould identification relies on the macroscopic and microscopic observation of colonies grown on mycological media [28]

In the current study, identification of filamentous fungi (28 isolates) was mainly phenotypically. Genotypic identification via sequencing of rRNA gene was carried out for some isolates. A. flavus was the most common isolated species $(10,35.6 \%)$, followed by A. niger $(9,32.1 \%)$, A. parasiticus (2, $7.1 \%$ ) and A. terreus, A. tubingensis, A. fumigatus, Absidia corymbifera, penicillium chrysogenum, Rhizopus oryzae, Syncephalastrum monosporum (3.6\% each). These results were consistent with those of Taura et al., [23] that found among 111/200 (55.5\%) positive sputum samples Aspergillus spp. was the most common isolated species (36.94\%).

Antifungal susceptibility testing methods are available to detect antifungal resistance and to 
determine the best treatment for a specific fungus. Clinical microbiology relies on these methods to select the agent of choice for a fungal infection, and to know the local and the global epidemiology of antifungal resistance [6].

Recently, resistance to common antifungals has been reported in different Candida species [29]. In addition, fungal strains isolated from immunocompromised patients have higher resistance to antifungals because of using antifungals as prophylaxis [30].

In our study, in-vitro susceptibility for yeast strains was performed using disc diffusion method and found that the most effective antifungals were Nystatin (90.9\% sensitivity), Amphotericin B $(80.3 \%)$ and Voriconazole (39.4\%). These results agree with those of Khan et al., [31] who reported that the most effective drugs for their isolates were nystatin and amphotericin-B and with Taghizadeh et al., [32] who found that $95.6 \%$ of Candida species isolated from Bronchoalveolar Lavage samples was sensitive to nystatin. Also, Bustamante et al., [33] reported that $98.0 \%$ of the isolates were susceptible to amphotericin B.

Resistance to Azoles and polyenes continues to increase and is a matter of concern as this is the most commonly used empirical therapy for suspected fungal infections [34]. In our study, the resistance of yeast isolates against antifungal drugs was most commonly seen against Itraconazole $(65.2 \%)$ followed by fluconazole $(57.6 \%)$, Voriconazole $(53 \%)$ then ketoconazole $(51.5 \%)$.

Determination of in vitro antifungal susceptibility pattern of mould strains showed that the highest sensitivity to Voriconazole $(71.4 \%)$ followed by Amphotericin B (57.1\%) and Nystatin $50 \%$, while the highest resistance was to Fluconazole $(92.8 \%)$ followed by Itraconazole $(75 \%)$. These results in our study match with Pfaller et al., [35] who found that the most active drugs against 239 clinical isolates of filamentous fungi were voriconazole (91\%) followed by amphotericin B (89\%) and with Sheneef et al., [36] who reported that filamentous fungi showed the highest sensitivity to Voriconazole $(93.48 \%)$ while all isolates were resistant to Fluconazole and with Messer et al., [37] who found that the newer triazoles (e.g., voriconazole and ravuconazole) displayed the greatest spectrum of activity against Aspergillus spp.

\section{Conclusion:}

Our study concluded that the most common fungal pathogens causing pulmonary fungal infec- tions at Assiut University Hospital were Candida and Aspergillus species. Culturing on chromogenic media such as CHROMagar Candida and Brilliance candida agar and application of API Candida strips proved to be of great value for preliminary identification of yeast isolates and represent a useful tool to detect mixed fungal infections. Molecular identification methods may be more expensive, but are more accurate. Antifungal susceptibility testing was of great value to exclude ineffective antifungal agents and allow better selection of the most active drugs.

\section{Conflicts of interest:}

There are no conflicts of interest.

\section{Acknowledgment:}

A great thanks for Faculty of Medicine, Assiut University for its financial support and Assiut University Mycology Center (AUMC), Faculty of Science for providing us with all kinds of facilities.

Financial support and sponsorship: A grant from the Faculty of Medicine, Assiut University was provided.

\section{References}

1- RAVIKANT K.T., GUPTE S. and KAUR M.: A Review on Emerging Fungal Infections and Their Significance. J. Bacteriol. Mycol., 1: 9-11, 2015.

2- MEERSSEMAN W., LAGROU K., MAERTENS J. and VAN WIJNGAERDEN E.: "Invasive aspergillosis in the Intensive Care Unit". Clin. Infect. Dis., 45 (2): 205-16, 2007.

3- LAMOTH F. and ALEXANDER B.D.: Nonmolecular methods for the diagnosis of respiratory fungal infections. Clinics in laboratory medicine, 34 (2): 315-36, 2014.

4- BADIEE P. and HASHEMIZADEH Z.: Opportunistic invasive fungal infections: diagnosis \& clinical management. The Indian Journal of Medical Research, 139 (2): 195,2014

5- MONTAGNA M.T., CAGGIANO G., LOVERO G., De GIGLIO O., CORETTI C., CUNA T., IATTA R., GIGLIO M., DALFINO L., BRUNO F. and PUNTILLO F.: Epidemiology of invasive fungal infections in the Intensive Care Unit: Results of a multicenter Italian survey (AURORA Project). Infection, 41 (3): 645-53, 2013.

6- ALASTRUEY-IZQUIERDO A., MELHEM M.S., BONFIETTI L.X. and RODRIGUEZ-TUDELA J.L.: Susceptibility test for fungi: Clinical and laboratorial correlations in medical mycology. Revista do Instituto de Medicina Tropical de São Paulo, 57: 57-64, 2015.

7- PFALLER M.A.: Antifungal susceptibility testing. In: Up to date, 2015.

8- ELLIS D., DAVIS S., HANDKE R. and BARTLEY R.: Description of medical fungi second edition. Mycology Unit, Women's and Children's Hospital. North Adelaide Australia book: 181-7, 2007. 
9- World Health Organization: Laboratory manual for diagnosis of fungal opportunistic infections in HIV/AIDS patients. Geneva: World Health Organization, 60-62, 2009.

10- RAPER K.B. and FENNELL D.I.: The Genus Aspergillus, the Williams and Wilkins Company, Baltimore, USA 1965.

11- MOUBASHER A.H.: Soil Fungi in Qatar and other Arab Countries, the Centre for Scientific and Applied Research, University of Qatar, Doha, Qatar, 1993.

12- WHITE T.J., BRUNS T., LEE S. and TAYLOR J.: Amplification and direct sequencing of fungal ribosomal RNA genes for phylogenetics. In: PCR Protocols: A guide to methods and applications. (Innis MA, Gelfand DH, Sninsky JJ, White TJ, eds). Academic Press, New York, USA: 315-22, 1990.

13- http://www.ncbi.nim.nih.gov. National Center of Biotechnology Information web site.

14- CLSI: Reference method for antifungal disk diffusion susceptibility testing of yeasts; approved guideline. NCCLS document M44: A. National Committee for Clinical Laboratory Standards Wayne, 2011.

15- CLSI: Method for antifungal disk diffusion susceptibility testing of non dermatophyte filamentous fungi; approved guideline. CLSI document M5 1-A. Clinical and Laboratory Standards Institute, Wayne, 2010.

16- ADISA J.O., MOHAMMED B., EGBUJO C.E. and BUKAR M.A.: Cytologic assessment of pulmonary aspergillosis in immune-compromised subjects in Maiduguri North Eastern, Nigeria, 2013.

17-LIMPER A.H.: The changing spectrum of fungal infections in pulmonary and critical care practice: Clinical approach to diagnosis. Proceedings of the american thoracic society, 7 (3): 163-8, 2010.

18- NJUNDA A.L., EWANG A.A., KAMGA L.H.F., NSAGHA D.S., ASSOB J.C.N., NDAH D.A. and KWENTI T.E.: Respiratory tract Aspergillosis in the sputum of patients suspected of tuberculosis in Fako divisionCameroon. Journal of Microbiology Research, 2 (4): 6872, 2012.

19- ZARRINFAR H., SABER S., KORDBACHEH P., MAKIMURA K., FATA A., GERAMISHOAR M. and MIRHENDI H.: Mycological microscopic and culture examination of 400 bronchoalveolar lavage (BAL) samples. Iranian Journal of Public Health, 41 (7): 70, 2012.

20- KOZEL T.R. and WICKES B.: Fungal diagnostics. Cold Spring Harbor perspectives in medicine, 4 (4): a019299, 2014.

21- GUPTA N.K., UPDESH S., KUMAR R. and KHURANU S.: Study of Fungi Associated with Biochopulmonary Disorders. Indian J. Med. Sci., 50: 333-6, 2012.

22- NASIR I.A., TALLE M., HAMIDU I.M., MURSAL A., DIKWA K.B., JELILI M. and Musa P.O.: Prevalence and profile of pulmonary fungal pathogens among HIV infected patients attending University of Maiduguri Teaching Hospital, Nigeria. The Egyptian Journal of Internal Medicine, 29 (1): 11, 2017.

23- TAURA D.W., ADAMU S., KOKI Y.A., MUSA M.A. and MUHAMMAD B.B.: Mycotic infections associated with pulmonary symptoms in patients attending Infectious
Diseases Hospital, Kano. Greener Journal of Microbiology and Antimicrobials, 2 (1): 015-020, 2014.

24- CORZO-LEON D.E., ALVARADO-MATUTE T., COLOMBO A.L., CORNEJO-JUAREZ P., CORTES J., ECHEVARRIA J.I., GUZMAN-BLANCO M., MACIAS A.E., NUCCI M., OSTROSKY-ZEICHNER L., PONCEDE-LEON A., QUEIROZ-TELLES F., SANTOLAYA M.E., THOMPSON-MOYA L., TIRABOSCHI I.N., ZURITA J. and SIFUENTES-OSORNIO J.: Surveillance of Candida spp bloodstream infections: Epidemiological trends and risk factors of death in two Mexican tertiary care hospitals. PloS one, 9 (5): e97325, 2014.

25- SARDI J.C.O., SCORZONI L., BERNARDI T., FUSCOALMEIDA A.M. and GIANNINI M.M.: Candida species: current epidemiology, pathogenicity, biofilm Gaballah A.H., Abdallah A., Fadel S. and El-Kholy M.A. (2017): Automated Identification and Antifungal Susceptibility Testing of Candida Species using Vitek 2 Compact formation, natural antifungal products and new therapeutic options. Journal of Medical Microbiology, 62 (1): 10-24, 2013.

26- MAGALHÃES Y.C., BOMFIM M.R.Q., MELÔNIO L.C., RIBEIRO P., COSME L.M., RHODEN C.R. and MARQUES S.G.: Clinical significance of the isolation of Candidaspecies from hospitalized patients. Brazilian Journal of Microbiology, 46 (1): 117-23, 2015.

27- SHAWKY S.M.: System in ICUs and Pediatric Oncology Unit, Alexandria, Egypt. The Egyptian Journal of Medical Microbiology (EJMM), 26 (2).

28- CASSAGNE C., RANQUE S., NORMAND A.C., FOURQUET P., THIEBAULT S., PLANARD C., HENDRICKX $M$. and PIARROUX R.: Mould routine identification in the clinical laboratory by matrix-assisted laser desorption ionization time-of-flight mass spectrometry. PLoS One, 6 (12): e28425, 2011.

29- SHOKOHI T., BANDALIZADEH Z., HEDAYATI M.T. and MAYAHI S.: In vitro antifungal susceptibility of Candida species isolated from oropharyngeal lesions of patients with cancer to some antifungal agents. Jundishapur Journal of Microbiology, 4 (5): 19-26, 2001.

30- HADDADI P., ZAREIFAR S., BADIEE P., ALBORZI A., MOKHTARI M., ZOMORODIAN K., PAKSHIR K. and JAFARIAN H.: Yeast colonization and drug susceptibility pattern in the pediatric patients with neutropenia. Jundishapur Journal of Microbiology, 7 (9), 2014.

31- KHAN P.A., FATIMA N., NABEELA S., KHAN H.M. and MALIK A.: Antifungal susceptibility pattern of Candida isolates from a tertiary care hospital in north India: A five-year study. Int. J. Curr. Microbiol. App. Sci., 177$81,2015$.

32- TAGHIZADEH A.M., HEDAYATI M.T., MAHDAVI O.S., SABER S., ABASTABAR M. and HOSSEINNEJAD A.: Identification and Antifungal Susceptibility Testing of Candida species isolated from Bronchoalveolar Lavage samples. Bustamante B., Martins M.A., Bonfietti L.X., Szeszs M.W., Jacobs J. and Garcia C.: Species distribution and antifungal susceptibility profile of Candida isolates from bloodstream infections in Lima, Peru. Journal of medical microbiology, 63 (6): 855-60, 2014.

33- BUSTAMANTE B., MARTINS M.A., BONFIETTI L.X., SZESZS M.W., JACOBS J. and GARCIA C.: Species 
distribution and antifungal susceptibility profile of Candida isolates from bloodstream infections in Lima, Peru. Journal of Medical Microbiology, 63 (6): 855-60, 2014

34- MAR MASIÁ CANUTO and FÉLIX GUTIÉRREZ RODERO: Antifungal drug resistance to azoles and polyenes. Lancet Infect. Dis., Vol. 2, 2002.

35- PFALLER M.A., MESSER S.A., HOLLIS R.J., JONES R.N. and Sentry Participants Group: Antifungal activities of posaconazole, ravuconazole, and voriconazole compared to those of itraconazole and amphotericin B against 239 clinical isolates of Aspergillus spp. and other filamentous fungi: Report from SENTRY Antimicrobial Surveillance
Program, 2000. Antimicrobial agents and chemotherapy, 46 (4): 1032-7, 2002

36- SHENEEF A., HASSAN H., ALI K.A., SAAD-ELDIN M. and ESMAIL A.: Identification and in vitro Susceptibility Pattern of Fungal Infection Isolated from Patients with Otomycosis. The Egyptian Journal of Medical Microbiology (EJMM), 26 (3), 2017.

37- MESSER S.A., JONES R.N. and FRITSCHE T.R.: International surveillance of Candida spp. and Aspergillus spp.: Report from the Sentry Antimicrobial Surveillance Program (2003). Journal of Clinical Microbiology, 44 (5): 1782-7, 2006.

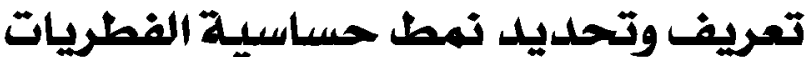

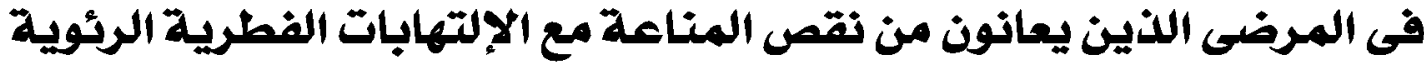

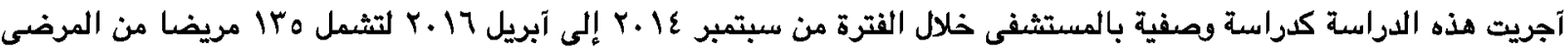

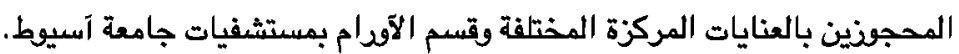

تم تصميم هذا العمل بتعريف آنواع الفطريات التى تسبب العدوى الرئوية فى المرضى الذين يعانفن من نقص المناعة وإجراء إختبار حساسية اللفطريات المعزولة لعدد من المضادات العراع الفطرية.

في هذه الدراسة، آظهر الفحص المجهرى المباشر للعينات آن V عينة تم تشخيصها كإيجابية للعدوى الفطرية بينما كانت .1 عينة إيجابية

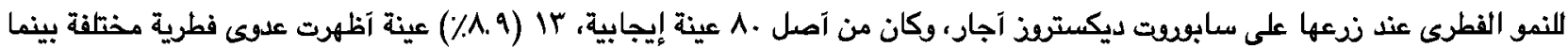

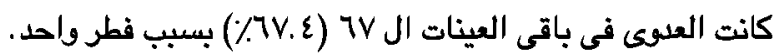

وقد تم إستخدام الطرق التقليدية من آجل التعرف على الخمائر المعزولة والتى شملت على ندع العينات على الوسائط الصبغية (البريليانس

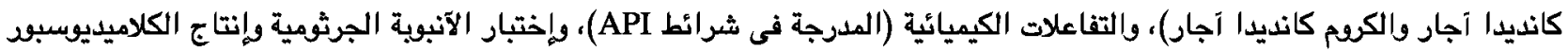

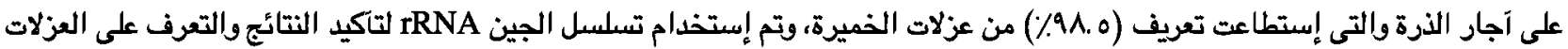

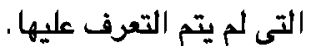

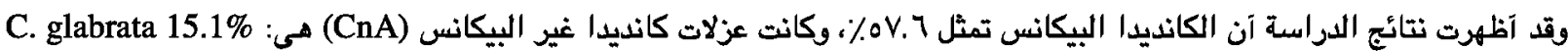
Saccharomyces cerevisiae 3\% وكانت نسبة الخمائر غير الكانديدا كما يلى الئ C. Kefyer 1.5\%, C. krusei 6.1\%, C. tropicalis 15.1\%, .Hanseniaspora guilliermondii $1.5 \%$,

آما بالنسبة اللفطريات الذيطية فكان التعرف على نوع الفطر من خلال الخصائص الميكروسكوبية والمظهرية وتاكيد تعريفها بإستخدام

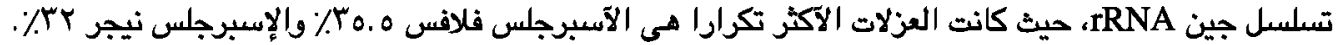

وقد آظهر تحديد نمط الصساسية لمضادات الفطريات المختلفة لسلالات الخميرة آن الآمفوتريسين بى متبوعا بالنيستاتين والفوكونانيل

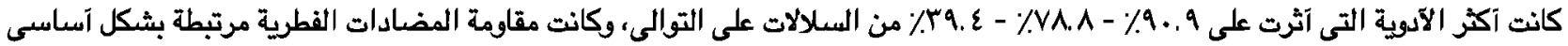

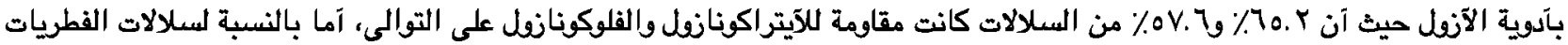

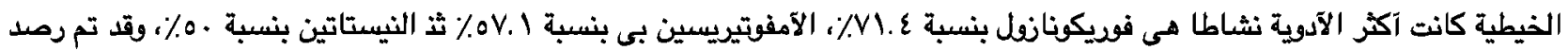

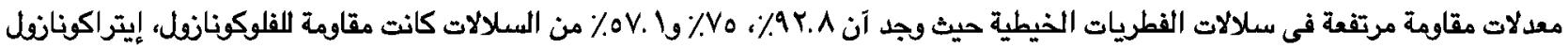

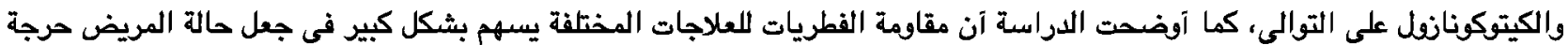

